\title{
Degrees of separation
}

What is the connection between recombinant pharmaceutical giant, Amgen (Thousand Oaks, CA) and sequencing-by-hybridization specialist, HySeq (Sunnyvale, CA). One answer is that George Rathman, founder and former chairman of Amgen, became CEO of HySeq in May this year. But an equally valid response, albeit one of which William of Occam would not approve, is that Amgen continues to fight in the US courts for rights to erythropoetin with Transkaryotic Therapies, which has nevertheless applied to US and European regulators for approval to launch an erythropoietin product with Aventis Healthcare which, in the meantime, has received antitrust clearance for its $\mathbf{\$ 4 5 0}$ million research alliance with Millenium Pharmaceuticals, whose first pharmaceutical partner, Hoffmann-La Roche has agreed to expand its marketing agreement on the polymerase chain reaction with PE Biosystems Group, whose sister company, Celera Genomics, announced a five-year comprehensive genomics agreement with Immunex Corporation, which has signed a deal for the development of an antibody against human epidermal growth factor with Abgenix, which signed a marketing and sales agreement for antibody therapy for graft versus host disease with Sangstat, which has settled its cyclosporine patent dispute with Novartis, whose Agricultural Discovery Institute has developed a commercial gene chip for Arabidopsis with Affymetrix, which has received a Markman judgement in its patent dispute with Hyseq.

\section{AHP sells Immunex stake}

American Home Products (Madison, NJ) is to sell about 50 million shares in Seattle-based Immunex. At the same time, Immunex plans to sell 20 million shares in a primary offering. The announcements in mid August propelled Immunex share price downward initially but analysts are still maintaining "strong buy" recommendations. The moves appear to be part of a general tidying up of the relationships between the two companies, a process that will loosen Immunex' ties to its de facto parent. American Home's ownership will fall to $45 \%$ from $53 \%$ now and it will lose one of its three seats on the board; it will acquire a manufacturing facility in Rhode Island from American Home. The billion or so dollars it will raise will enable Immunex to invest over $\$ 500$ million in an R\&D center in Seattle to increase its production capability for its rheumatoid arthritis treatment Enbrel, and to pursue acquisitions or collaborations. $\quad J H$

\section{EvoTec buys Oxford Assym}

German drug discovery company EvoTec BioSystems (Hamburg) has acquired the UK firm Oxford Assymetry (Abingdon) in an all-share takeover bid worth around $\mathfrak{E} 316$ million ( $\$ 473$ million). This is the first time a German company has bought a UK biotech company, reflecting the growing strength of the German biotech sector. EvoTec said the acquisition would create a “'one-stop shop' for value-added drug discovery and development services". EvoTec specializes in ultra-high-throughout screening and assay development, but lacked the expertise in medicinal chemistry that Oxford Assymetry can provide. Evotec offered to buy Oxford Assymetry's shares at a $46 \%$ premium to the price at the close of last dealing day prior to the announcement. The enlarged company will have a market value of around $\$ 1.3$ billion, which will give it the critical mass to be competitive with other contract research companies such as Aurora Biosciences (San Diego, CA).

Companies with medicinal chemistry expertise have recently become highly attractive to drug discovery companies. In July, Millennium Pharmaceuticals (Cambridge, MA) paid $£ 33.5$ million ( $\$ 50$ million) for UK's Cambridge Drug Discovery (Cambridge, UK) in July-also at a significant premium.

\section{Cephalon acquires Anesta}

Cephalon (West Chester, PA) has agreed to purchase Anesta (Salt Lake City, UT) in an allshare deal worth $\$ 444$ million, providing the company with additional sales and marketing muscle, a high-growth oncology pain product, and access to a novel drug-delivery system. The acquisition fits well with Cephalon's strategy to become a specialist in niche markets for sleep and other neurological disorders and in cancer. Although Cephalon paid a $40 \%$ premium for Anesta's shares, Frank Baldino, Cepahlon's chair and CEO, said that the deal would "shorten Cephalon's time to profitability". In addition to Provigil, its treatment for sleepiness associated with narcolepsy, Cephalon will derive revenue from Actiq-Anesta's treatment for breakthrough cancer pain based on its patented oral transmucosal system.

Unfortunately for Anesta shareholders, shortly after the deal was announced, a 113patient double-blind, placebo-controlled trial showed that Provigil did not help treat attention deficit hyperactivity disorder. At the end of July, when Cephalon agreed to buy Annesta, Cephalon's shares were around \$66, or around $\$ 31.5$ per Anesta share. After the Provigil announcement, Anesta stockholders would be getting under $\$ 23.5$ worth of Cephalon shares per share.

$L F \& J H$

\section{Research collaborations

Company $1 \quad$ Company 2

UroGenesys

(Santa Monica, CA)

Genentech

(San Francisco, CA)

\begin{tabular}{|c|c|}
\hline $\begin{array}{l}\text { Maxygen } \\
\text { (Redwood City, CA) }\end{array}$ & $\begin{array}{l}\text { Karolinska Institute } \\
\text { (Stockholm, Sweden) }\end{array}$ \\
\hline $\begin{array}{l}\text { Origen Therapeutics } \\
\text { (Burlingame, CA) }\end{array}$ & $\begin{array}{l}\text { Embrex } \\
\text { (Research Triangle, } \\
\text { Park NC) }\end{array}$ \\
\hline $\begin{array}{l}\text { Lorus Therapeutics } \\
\text { (Toronto, Canada) }\end{array}$ & $\begin{array}{l}\text { AVI BioPharma } \\
\text { (Portland, OR) }\end{array}$ \\
\hline
\end{tabular}

"Financial details not disclosed.

\section{\$million Details}

33

An agreement to develop antibody-based therapeutics for prostate and bladder cancer using prostate stem cell antigen (PSCA) as a target. In exchange for exclusive worldwide rights to PSCA, and a panel of monoclonal antibodies, UroGenesys could receive $\$ 33$ million in funding and milestones, in addition to any royalties.

The two-year deal will employ Maxygen's directed molecular evolution technology to generate novel recombinant chimeric allergens, which Karolinska will test as immunotherapies for allergic conditions.

A deal to develop and produce chickens that grow quickly and reproduce easily using stem cell cloning technology. Origin will isolate and culture stem cells of desirable traits, and Embrex's injection technology will be used to mass produce chicken embryos.

A five-year agreement to evaluate and co-develop antisense drugs for cancer and infectious diseases. AVI will contribute its antisense backbone to the collaboration, while Lorus will provide disease targets and experimental knowhow, and both companies will share resulting intellectual property. 